\title{
ELECTIONS: AN EXPLORATION OF THEORETICAL POSTULATIONS
}

\author{
Emmanuel O Ojo \\ Dr Emmanuel O Ojo is a Senior Lecturer in the \\ Department of Political Science of the University of Ilorin, \\ Kwara State, Nigeria \\ P M B 1515, Ilorin \\ Tel: +08033822383 (mobile); Tel: +022008330 (home) \\ e-mail: eojo12000@yahoo.com
}

\begin{abstract}
There is no doubt that a free and fair election is a sine qua non for electoral democracy, but not every election fulfils these criteria. Against this premise this paper attempts to explore theoretical postulations vis-à-vis elections. With brief introductory remarks emphasising the importance of elections to democratic sustenance and consolidation, the paper proceeds to examine the democratic utility of elections in all regions and climes and the misconception that elections held regularly are an end in themselves and not a means to an end. The third section dwells on the necessary prerequisites for the conduct of a free and fair election, thereby bringing out the peculiar existential reality of African politics. The paper infers that democratic sustenance via elections may not be easily attainable until African politicians become democrats themselves. This is not unconnected with the fact that no polity can nurture democracy until democrats evolve.
\end{abstract}

\section{INTRODUCTION}

Since the advent of democratisation in Africa in the 1990s a great deal of emphasis has been placed on holding regular elections (Molomo 2006). It is generally agreed that in all regions and climes of the world elections are a hallmark of democracy and an important instrument through which leaders are elected to public office (Molomo 2006, p 23). Exploring the nexus between democratic rules and elections Aristotle averred that '... from these fundamental principles, and in particular the principles of ruling and being ruled are derived the following features of 
democracy: (1) elections: all citizens eligible for all offices...' (Cited in Cola 1980 $\mathrm{p} 1$ ). This perception from the past epitomises the central argument of this paper vis-à-vis the importance of elections to both the sustenance and the consolidation of democracy in both advanced and developing democracies.

Meanwhile, the major distinction between electoral democracy and electoral constitutionalism builds upon the common affirmation that democracy requires elections, but not just any kind of elections. The idea of democratic self-government is incompatible with electoral farces (Ojo 2006c, p 105). In the common phrasing, elections must be free and fair in order to pass as democratic. Under electoral democracy contests comply with minimal democratic norms; under electoral authoritarianism, they do not (Schedler 2002, pp 36-50). In an electoral democracy a free and fair election is indeed a sine qua non for an ideal democracy. No polity can be adjudged democratic if elections are not free and fair. Taking a cue from Jeane Kirkpatrick, scholar and former US Ambassador to the United Nations (cited in What is Democracy? 1991, pp 16,17), 'democratic elections are not merely symbolic...They are competitive, periodic, inclusive, definitive elections in which the chief decision-makers in a government are selected by citizens who enjoy broad freedom to criticise government to publish their criticism and to present alternatives.'

Be that as it may, elections are the process of choosing people for particular jobs by voting. There are two major types of election - direct and indirect. In the case of the former voters participate directly, electing their representatives. The process of direct election is very simple. Each voter goes to the polls and records a vote in favour of one candidate or another. The candidate securing the maximum number of votes is declared elected. This method of election is the most popular and is used in all democratic countries to elect members of the representative chambers.

When a system of indirect election is in force voters do not participate directly in the election of their representatives but elect an intermediary body which, alone, makes the final choice. This intermediary body is usually known as an electoral college and the system involves a double election, which limits the power of the voters (Kapur 2006, pp 519-520).

A major advantage of direct election is that it makes people conscious of their rights and duties and is fully in keeping with democratic principles. Direct contact between voters and their representatives stimulates interest in public affairs and develops a sense of public spirit. It also sharpens the political intelligence of the people. Democracy has an educative value and there is no better way of educating citizens than giving them the opportunity to participate directly in the election of their representatives. The spirit of political vigilance so injected in the people enables them to judge whether their representatives justify 
the trust reposed in them (Kapur 2006, p 520). Irreverent critics have, however, vehemently opposed direct election, maintaining that voters are not necessarily in a position to exercise their political rights wisely (Kapur 2006).

Generally, in the global North, with the existence of solid structures for good and efficient governance, politicians are chosen for their particular qualities. Political parties do their homework thoroughly in the search for those to represent them at the polls so that they will not be disgraced. In contrast, in the global South, generally, the parties force their representatives, irrespective of their background, on the electorate. Most of these parties do not follow the rule of law but engage in fake primaries and strive to win elections by all means. They come to power crudely and behave selfishly. In essence, parties are unable to field people of sterling qualities (Ajakaye 2007, p 11).

The second section of the paper examines the democratic utility of elections, which concerns the basic function of elections in a democratic setting. The section is followed by the prerequisites for free and fair elections and the requirements for an election to be of democratic value. The paper infers that the attainment of an ideal electoral system is still the ultimate aim of virtually all democratic polities.

\section{THE DEMOCRATIC UTILITY OF ELECTIONS}

The link between elections and democracy is clear, for, thus far, no superior method has been evolved for selecting the leadership of a democratically ruled society (Ogunsanwo 2003, p 11). Thus, democratic elections provide the answer to the fundamental question: who leads a people and under what agenda? This proposition argues further that elections are the primary stage in the realisation and maintenance of the common good sought by a people (Alao 2004, p v). In that vein elections, broadly conceived, refer to the process of elite selection by the mass of the population in any given political system (Anifowose 2003, p 21).

For a wider variety of political systems - competitive and non-competitive, developed and developing, Afro-Asian, communist and Western - there seems to be a general acceptance that elections are the means by which popular commitment to the regime may be mobilised. Indeed, some scholars have gone further and portray elections as the very heart of democracy (Anifowose 2003, p 21). In the words of Schumpeter (1942) democracy is an 'institutional arrangement', a means of filling public office through a competitive struggle for the people's vote. According to Ojo (2003a) 'elections do not only serve the purpose of peacefully changing government, it also enhances and confers political legitimacy on the government'. This is done through involving citizens in political decisionmaking. Put differently, elections are the instrument through which people choose their leaders and keep them accountable. 
Ostensibly, elections are institutional mechanisms that implement democracy by allowing citizens to choose among candidates or issues. But elections also serve several other important purposes:

- Elections socialize political activity. They transform what might otherwise consist of sporadic citizen-initiated acts into a routine public function. That is, the opportunity to vote for change encourages citizens to refrain from demonstrating in the streets. This helps preserve government stability by containing and channelling away potentially disruptive or dangerous forms of mass political activity.

- Elections institutionalise access to political power. They allow ordinary citizens to run for political office or to play an important role in selecting political leaders. Working to elect a candidate encourages the campaign worker to identify problems or propose solutions to the new official.

- Elections bolster the state's power and authority. The opportunity to participate in elections helps convince citizens that the government is responsive to their needs and wants, which increases its legitimacy. Janda, Berry and Goldman 1992, p 259

In an insightful work, Anifowose (2003, p 24) notes that elections do not possess one single character or function. He identifies the following function of elections:

- Recruiting politicians and public decision-makers.

- Making governments.

- Providing representation.

- Influencing policy decisions.

- Educating voters.

- Building legitimacy.

- Strengthening elites.

- Providing succession in leadership.

- Extension of participation to many people.

Anifowose (2003) goes on to distinguish two broad purposes or functions served by an election, which serve as models differentiating various electoral systems. The two purposes are, first, the competitive model where the elite compete for office, and, second, the non-competitive or ratificatory model, based on the ratification of elite preference by the mass electorate. The competitive model emphasises party competition and a possible change of government through elections, while the ratificatory model is characterised by the exclusion of critical 
opposition, unfair electoral regimes and single-party systems, that is, the absence of party competition. For any electoral system or election to perform the abovementioned functions it must satisfy a number of conditions. It is those prerequisites to which we now turn, with the attendant limitations in the African context.

\section{PREREQUISITES FOR A FREE AND FAIR ELECTION}

Undoubtedly all the elements of free and fair elections are difficult to come by, though they are a necessity in the attainment of a democratic polity, but a minimum number of such prerequisites is required for democracy to be consolidated (see Ojo 2006c, pp 3-24). This is because the epistemic conception of democracy proceeds from the position that there is a common good (common will) independent of voters' preference but towards which an aggregation of voting can point. The voting process is a truth-searching process. Joshua Cohen, cited in Alao (2004, p viii), argues that every epistemic conception of democracy is based upon three elements.

(a) An independent standard of correct decision-making, that is, an account of justice or of the common good that is independent of current consensus and the outcome of votes.

(b) A cognitive account of voting, that is, the view that voting expresses views about current policies according to an independent standard, not personal preferences for policies.

(c) An account of decision-making as a process of adjustment of beliefs, adjustments undertaken in part in the light of evidence about the correct answers provided by the beliefs of others.

Following from the above is the fact that there is a need for a free flow of information in order for people to be as objective as possible in making up their minds about social and political issues. But even though media machines are non-social the men and women who programme information into them are social beings, with biases, preferences and prejudices (Olorode 1990, p 3). Benn (1981) also correctly grasped the power of the media in relation to democracy when he wrote that the media 'have the power to decide how news is to be covered, who is to be covered, who is to be invited to comment, and who is not to be invited ...' There is no doubt that the mass media have an enormous role to play in the process of democratic sustenance and free and fair elections. As I have argued elsewhere (Ojo 2003b), the media are imperative to democracy, although they are susceptible to manipulation by the elite, a problem I have addressed extensively elsewhere (Ojo 1999, 2002, 2003b, 2006a, and 2007). Nigeria has a vigorous press 
which is reasonable and, to a great extent, independent, a major plus for the country's march to democracy.

Perhaps the most potent prerequisite for the conduct of a free and fair election, particularly in Africa, is the state's capacity to achieve one. In any polity where the state is weak and soft the hope of an improved electoral system becomes a mirage. In the literature state power is said to consist of the following five elements: monopoly of the coercive power of society, that is, control of the instruments of coercion; the right to impose taxes and collect revenue; the power to make laws; sovereignty over territory and society; and control of the institutions of the state or the state apparatus/bureaucracy (Onyeoziri 2005, p 3). These five elements endow the state with the status of statehood. But nation states which qualify for the status of statehood may differ in their degree of stateness (Nettle 1963; Tilly 1975) - some are strong, others are weak.

The 2007 elections showed that there is little law and order in Nigeria. Neither the state nor its agencies and operators readily obey court orders; citizens frequently resort to taking their own action rather than go to court; trust in the judiciary is low; suspicion of the police as the principal law enforcement agency and belief that that vital institution is corrupt is high and justice is frequently delayed and, at times, denied.

Consequently, Nigerians frequently resort to extra judicial remedies (Onyeoziri 2005, pp 5, 6). This situation did enormous damage to the credibility of the last general elections, as subsequent papers demonstrate glaringly. A great deal of violence was inflicted on citizens, particularly in the south-western parts of the country, to the extent that Chief Olusegun Obasanjo, then sitting president, admitted publicly that some political godfathers should be tolerated despite their political misdemeanours and heinous crimes against helpless citizens during the elections.

Violence was so extreme that hoodlums who went on the rampage injuring newscasters and vandalising equipment succeeded in shutting down the Oyo State Broadcasting Corporation for more than a month. By the time of writing no suspect had been arrested. After the elections the ruling party in the state claimed responsibility and apologised on air. Such incidents prove that Nigeria is far from able to conduct a free and fair election.

Another important prerequisite for the conduct of free and fair elections is the ability of the electoral body to deliver. Nigeria's Independent National Electoral Commission (INEC) was far from independent in its administration of the 2007 general elections.

In a perceptive study Elklit \& Reynolds (2000) emphasise the significant role of election bodies in the successful conduct of elections. It is important for electoral bodies to be truly autonomous of the executive arm of government and 
the ruling party, to be independent and be seen to be so - legally, structurally, financially and in all other respects.

The personnel who head the national electoral body and the national commissioners should be appointed in a manner that truly confers on them the garb of independence and, more critically, independence of thought and action. To achieve this, the appointment of electoral commissioners and their principal officers must be rooted in a system which does not allow a sitting president or governor to appoint the umpires who will supervise elections in which they are participants or have a personal interest (Tinubu 2007, p 8). Only under such a system will the people's confidence in the election process be restored. The arrangement should be akin to the judiciary's consolidated fund, which cannot be tampered with by the executive.

Where the reverse is the case two sets of problems may arise with the voting process - those related to non-compliance with electoral law and those related to fraud (corruption) during vote counting. With respect to the first set the vote is considered democratic if the voting procedure is democratic. According to Alao (2004) the procedure is democratic if all the following conditions are met.

(a) Every preference is freely revealed, that is, the process is free.

(b) The playing field is level for all candidates.

(c) Every valid vote counts.

(d) There is no single vote whose preference automatically determines a majority, that is, there is no autocracy.

(e) No 'proxy' votes are allowed.

Alao (2004, $\mathrm{p}$ vii) observes further that fraud in the counting process is often systematically organised and that:

(a) the greater the degree of centralisation of power the greater the possibility of vote rigging;

(b) the larger the government the more forms of vote rigging there are;

(c) the lower the degree of accountability of government/representatives, the higher the level of corruption;

(d) in an environment of poverty, votes may acquire a market value determined by competition among the rich who wish to acquire power in addition to wealth. So, poverty may entrench a [corrupt] plutocracy.

Setting out the prerequisites for a free and fair election Mackenzie (1958) avers that the effective functioning of a competitive electoral system requires, first, an 
independent judiciary to interpret the electoral law; second, an honest competent, non-partisan administration to run the elections; third, a developed system of political parties organised to put their policies and teams of candidates before the electorate; fourth, a general acceptance by the political community of certain rather vague rules of the game, which limit the struggle for power. Almond \& Verba (1963) added that facilitating factors are the norms, traditions, and attitudes of social cooperation and interpersonal trust and high levels of consensus which must permeate the political process. In this vein, Aron (cited in Anifowose 2003, p 36) declares: 'What is necessary for competition between parties is that two different parties should accept the rule of the game, that they should have the feelings that the unity of the nation is a good, in itself, which should be maintained.'

Hence, the success of the electoral system requires a certain forbearance, tolerance of the opposition, and willingness to play by the rule of the game. Any flaw in the election rules and administration prevents the full achievement of this objective and constitutes a matter of great concern to democracy. As Anifowose (2003) notes further, one of the most prevalent deviations from this standard is fraud - the illegal manipulation of voting, ballots and the counting process by individuals or groups for the purpose of winning more votes than they otherwise could. There is no gainsaying that the history of elections in post-colonial Africa shows that the assumption of the competitive model is compromised by electoral manipulation.

Among the widespread methods used to rig elections are 'padding the register [putting fictitious names on the voters' roll]', 'intimidation and bribery of voters', and 'stuffing the ballot box'.

Nevertheless, it must be emphasised too that a corrupt system with a high rate of unemployment, extreme poverty and widespread illiteracy cannot produce a credible election. For instance, in the 2007 elections INEC used ad hoc staff for most of its election duties, the bulk of them drawn from the army of unemployed youths in the country. Independent sources put the unemployment figures at between 65 and 70 per cent (Tell 7 May 2007) and the United Nations Development Programme estimates that nine out of ten Nigerians live on less than $\$ 2$ per day. As at 2005 Nigeria was rated the 20th poorest nation in the world and listed as 146 of 182 on the United Nations Human Development Index. In 2006 the World Bank rated the country as among the 57 with the lowest incomes while the human index for 2006 ranked the country as 159 of 171 in terms of life expectancy, educational attainment and real income (Tell, 7 May 2007). Thus, whatever the dimension of electoral reform, the issue of poverty must be resolved in anticipation of a credible election. 


\section{CONCLUSION}

In this paper we have theoretically analysed what it takes to guarantee a credible electoral system. It must, however, be emphasised that the factors highlighted are far from being exhaustive as such prerequisites as incumbent rascality, whereby state machinery is deployed to vent its anger on the opposition - a sort of 'sittight' syndrome, coupled with the use of naked power to intimidate perceived enemies - could not be analysed because of space constraints.

To sum up: there cannot be a credible election where there are no democrats. Democracy is about imbibing democratic instincts.

We now turn to empirical details of Nigeria's 2007 general election.

\section{- REFERENCES}

Ajakaye, F. 2007. 'Elections 2007: Real Do-or-Die-Affairs'. The Guardian, Lagos, 22 April.

Alao, N. 2004. 'Foreword'. In L Olurode \& R Anifowose (eds). Issues in Nigeria's 1999 General Elections. Lagos: John West and Rebonik Publications.

Anifowose, R. 2003. 'Theoretical Perspectives on Elections'. In R Anifowose \& T Babawale. 2003 General Elections and Democratic Consolidation in Nigeria. Lagos: Friedrich Ebert Stiftung and Frankad Publishers.

Benn, T. 1981. Arguments for Democracy. Midddlesex: Penguin Books.

Cola, L. 1980. 'A Survey Analysis of Voting Behaviour in Ibadan, Nigeria'. The Nigerian Journal of Economic and Social Studies 22(1).

Elklit, J \& A Reynolds. 2000. 'The impact of Election Administration on the Legitimacy of Emerging Democracies. A new Research Agenda.' Paper delivered at the 2000 Annual Meeting of the American Political Science Association, Marriott Wardman Park, Washington, DC, 31August-3 September.

Kapur, A C. 2006. Principles of Political Science. New Delhi: S. Chand and Company. Molomo, M G. 2006. 'Democracy and Botswana's Electoral System'. Journal of African Elections 5(2).

Nettle, J P. 1968. 'The State as a Conceptual Variable'. World Politics 20(2).

Ogunsanwo, A. 2003. 'Keynote Address: 2003 General Elections and Democratic Consolidation in Nigeria'. In R Anifowose \& T Babawale (eds). 2003 General Elections and Democratic Consolidation in Nigeria. Lagos: Friedrich Ebert Stiftung and Frankad Publishers.

Ojo, E O. 1999. 'The Role of the Press in a Transitional and Democratic Setting'. Herald on Sunday, Ilorin, 28 February. 
— . 2002. 'The Mass Media and the Challenges of Democratic Consolidation: A Comparative Study of Nigeria and the United States'. In S O O Amali et al (eds). Consolidation and Sustenance of Democracy. USA and Nigeria: American Studies Association of Nigeria (ASAN), Ibadan: Hope Publications.

_ 2003a. 'Governance and Legitimacy Crisis in Nigeria'. Research for Development $18(1 \& 2)$.

_ 2003b. 'The Mass Media and the Challenges of Sustainable Democratic Values in Nigeria: Possibilities and Limitations'. Media, Culture and Society 25(1).

— . 2006a. 'Press Freedom and Democratic Development'. In H A Saliu, J F Olorunfemi, U Lateef \& S B Oludoyi (eds). Democracy and Development in Nigeria: Conceptual Issues and Democratic Practice Vol 1. Lagos: Concept Publications.

— 2006b. 'Vote buying in Nigeria'. In Money, Politics and Corruption in Nigeria. Abuja: IFES, May.

— . 2006c. 'Imperatives of Sustaining Democratic Values'. In E O Ojo (ed). Challenge of Sustainble Democracy in Nigeria. Ibadan: John Archers.

— 2007. 'Fourth Estate of the Realm or Wreck: Media, Government and the Nigeria State'. Babcock Journal of Mass Communication 1(2).

Olorode, L. 1990. A Political Economy of Nigeria's 1983 Elections. Lagos: John West Publications.

Onyeoziri, F. 2005. 'Federalism `and State Capacity in Nigeria'. Ibadan Journal of the Social Sciences 3(2).

Schedler, A. 2002. 'Elections without Democracy: The Menu of Manpulation'. Journal of Democracy 13(2).

Schumpeter, J. 1942. Capitalism, Socialism and Democracy. London: Allen and Unwin. Tilly, C. 1975. 'Reflections on the History of State Making'. In C Tilly (ed). The Formation of National States in Western Europe. Princeton: Princeton University Press.

Tinubu, B A. 2007. 'Thoughts on the Electoral Reform Panel'. Sunday Tribune, Ibadan, 9 September. 